\title{
POTASSIUM CHANNEL OPENERS PREVENT POTASSIUM-INDUCED CALCIUM LOADING OF CARDIAC CELLS: POSSIBLE IMPLICATIONS IN CARDIOPLEGIA
}

José R. López, MD, PhD

Rashid Jahangir, MD

Arshad Jahangir, MD

Win K. Shen, MD

Andre Terzic, MD, $\mathrm{PhD}$
Hyperkalemic solutions that are used as cardioplegic agents, while effective in inducing electromechanical arrest, are only partially cardioprotective, and ventricular dysfunction has been observed. The underlying pathophysiology of cardioplegia-associated ventricular dysfunction is complex and not fully understood, but it could be related, in part, to intracellular $\mathrm{Ca}^{2+}$ loading induced by high $\mathrm{K}^{+}$concentrations present in cardioplegic solutions. Yet no effective cytoprotective means against possible intracellular $\mathrm{Ca}^{2+}$ loading, under these conditions, has been described. Recently, potassium channel openers, which open adenosine triphosphate-sensitive $\mathrm{K}^{+}$channels, have been reported to possess cardioprotective properties under global ischemic conditions. However, it is not known whether these novel agents could prevent intracellular $\mathrm{Ca}^{2+}$ loading that could occur during cardioplegia. Intracellular $\mathrm{Ca}^{2+}$ was monitored in ventricular myocytes, loaded with the $\mathrm{Ca}^{2+}$-sensitive fluorescent probe Fluo-3AM, using epifluorescent digital imaging and laser confocal microscopy. Exposure of a myocyte to a $16 \mathrm{mmol} / \mathrm{L}$ concentration of $\mathrm{K}^{+}$, a concentration of $\mathrm{K}^{+}$commonly used in cardioplegic solutions, induced a nonhomogeneous increase in intracellular $\mathrm{Ca}^{2+}$. Potassium channel opening drugs, such as aprikalim or nicorandil, effectively prevented these solutions from increasing intracellular $\mathrm{Ca}^{2+}$. The preventive effect of potassium channel opening drugs was antagonized by glyburide, a selective blocker of adenosine triphosphate-sensitive $\mathrm{K}^{+}$channels. This study demonstrates, at the single cardiac cell level, that solutions containing a $16 \mathrm{mmol} / \mathrm{L}$ concentration of $\mathrm{K}^{+}$ promote intracellular $\mathrm{Ca}^{2+}$ loading, which can be prevented by potassium channel opening drugs. Therefore, potassium channel opening drugs should be considered to prevent intracellular $\mathrm{Ca}^{2+}$ loading associated with the use of cardioplegic solutions. (J Thorac Cardiovasc Surg 1996;112:820-31)
C: ardioplegic solutions that contain high concentrations of $\mathrm{K}^{+}$have been used to achieve cardiac arrest and to protect the myocardium during cardiopulmonary bypass operations. ${ }^{1,2}$ Although effective

From the Division of Cardiovascular Diseases, Departments of Internal Medicine and Pharmacology, Mayo Clinic, Mayo Foundation, Rochester, Minn.

This study was supported by grants from the American Heart Association, the National Heart Foundation (Rockville, Md.), and the Pharmaceutical Research and Manufacturers of America Foundation (Washington, D.C.).

Received for publication July 5, 1995; revisions requested Sept. 5, 1995; revisions received Dec. 5, 1995; accepted for publication Jan. 26, 1996.

Address for reprints: Andre Terzic, MD, PhD, Division of Cardiovascular Diseases, Guggenheim 7, Mayo Clinic, Rochester, MN 55905.

Copyright $\odot 1996$ by Mosby-Year Book, Inc.

0022-5223/96\$5.00+0 $\mathbf{1 2 / 1 / 7 2 3 2 4}$ in inducing electromechanical arrest, cardioplegic solutions are only partially cardioprotective against global surgical ischemia. ${ }^{3-5}$ Despite various modifications implemented in hyperkalemic cardioplegic solutions, ventricular dysfunction is common and still contributes to the morbidity and mortality associated with cardiac surgery. ${ }^{6-8}$

The pathophysiology underlying cardioplegiarelated ventricular dysfunction is complex and, at present, not fully understood. ${ }^{6-8}$ However, myocardial cytosolic $\mathrm{Ca}^{2+}$ accumulation has been observed after a cardioplegic challenge and could play a role in the development of ventricular dysfunction., 90 The cellular mechanism of $\mathrm{Ca}^{2+}$ accumulation has been related, in part, to the high $\mathrm{K}^{+}$concentration present in conventional cardioplegic solutions. ${ }^{9}$

Neither the spatial distribution of intracellular $\mathrm{Ca}^{2+}$ changes induced by high $\mathrm{K}^{+}$-containing solutions nor effective cytoprotection against intracellu- 
lar $\mathrm{Ca}^{2+}$ loading has been defined in cardiac cells. Recently, potassium channel openers, which activate $\mathrm{K}^{+}$channels sensitive to adenosine triphosphate (ATP), have been shown to be cardioprotective during ischemic insults and may improve myocardial protection during global surgical ischemia. ${ }^{11}$ However, it is not known whether potassium channel openers are capable of protecting cardiac cells from $\mathrm{Ca}^{2+}$ loading during a high $\mathrm{K}^{+}$cardioplegic challenge.

The aims of the present study were as follows: (1) to determine intracellular $\mathrm{Ca}^{2+}$ changes in single cardiac cells exposed to high $\mathrm{K}^{+}$solutions; (2) to examine whether two currently used strategies to minimize myocardial injury, namely removing extracellular $\mathrm{Ca}^{2+}$ or adding extracellular $\mathrm{Mg}^{2+12-14}$ affect intracellular $\mathrm{Ca}^{2+}$ level in cardiac cells exposed to high $\mathrm{K}^{+}$solutions; and (3) to evaluate whether drugs that open potassium channels protect ventricular myocytes from intracellular $\mathrm{Ca}^{2+}$ changes induced by high $\mathrm{K}^{+}$solutions.

\section{Methods}

Cell isolation. Ventricular myocytes were isolated from guinea pig hearts by enzymatic dissociation. ${ }^{15}$ In the pentobarbital anesthetized and artificially ventilated animal, the aorta was rapidly cannulated and the heart retrogradely perfused through the coronary arteries at $37^{\circ} \mathrm{C}$ with the following solution: (1) normal Tyrode solution for 5 minutes to remove the blood, (2) nominally $\mathrm{Ca}^{2+}$-free solution for 5 minutes to cleave desmosomal and intermediate junctions, (3) nominally $\mathrm{Ca}^{2+}$-free solution containing collagenase $(0.04 \mathrm{gm} / 100 \mathrm{ml}$ Sigma type I, Sigma Chemical Company, St. Louis, Mo.) for 45 minutes to disrupt extracellular matrix, and (4) high $\mathrm{K}^{+}$-low $\mathrm{Cl}^{-}$ solution for 5 minutes to remove the collagenase and provide high-energy substrate to the partially digested myocardium. So that loosened myocytes could be released, a small piece of the collagenase-treated ventricle was dissected and agitated in dishes filled with Tyrode solution in which cells then rested. Isolated cardiac myocytes were used because they are a pure myocardial preparation with no neuronal or vascular elements, and the response of isolated cells is not affected by diffusion barriers between the surface and the core of the muscle or by changes in preload, afterload, or coronary flow. The experimental protocol was approved by the Institutional Animal Care and Use Committee at the Mayo Clinic (No A33-94).

Fluorescent probes. The $\mathrm{Ca}^{2+}$-selective fluorescent probe Fluo-3 acetoxymethylester (Fluo-3AM) was used to monitor relative changes in $\mathrm{Ca}^{2+}$ concentration. This probe exhibits lower binding capacity for $\mathrm{Ca}^{2+}$ and produces larger fluorescence signals after $\mathrm{Ca}^{2+}$ binding than conventional fluorescent probes. ${ }^{16}$ Aliquots of $50 \mu \mathrm{g}$ of Fluo-3AM were dissolved in $50 \mu$ l of dimethyl sulphoxide (DMSO) plus $6 \mu \mathrm{l}$ of a $25 \%$ solution of pluronic acid.
Ventricular myocytes were loaded for 45 to 60 minutes, at room temperature with Fluo-3AM $(10 \mu \mathrm{mol} / \mathrm{L})$. Then they were transferred to a coverlip mounted on the perforated bottom of an experimental chamber placed on the stage of an inverted epifluorescent or confocal microscope and superfused with Tyrode solution. Fluorescent measurements were carried out at room temperature $\left(23^{\circ} \mathrm{C}\right)$. In a separate set of experiments, cardiomyocytes were loaded with the ratiometric dye Fura-2 acetoxylmethylester (Fura-2AM; $10 \mu \mathrm{mol} / \mathrm{L}$ ) to quantify resting intracellular $\mathrm{Ca}^{2+}$ concentration. ${ }^{17}$

Epifluorescent digital microscopy. Rod-shaped ventricular myocytes with clear striation were imaged by digital epifluorescent microscopy by means of an inverted microscope (Zeiss Axiovert-135 TV, Carl Zeiss, Inc., Thornwood, N.Y.) with a $40 \times$ oil-immersion objective lens. Optimal focus was adjusted by viewing myocytes under bright field microscopy. A $100 \mathrm{~W}$ mercury lamp served as a source of light to excite Fluo-3AM at $488 \mathrm{~nm}$ (or Fura-2AM at 340 and $380 \mathrm{~nm}$ ). Fluorescence emitted at $520 \mathrm{~nm}$ by the "excited" dyes was captured, after crossing a dichroic mirror, by an intensified charge-coupled device camera and digitized using the epifluorescent imaging system (Attoflor RatioVision, Atto Instruments, Inc., Rockville, Md.). Background fluorescence (Tyrode solution containing no cells) was subtracted from the fluorescence of Fluo-3AM (or Fura-2AM)-loaded myocytes.

Laser confocal microscopy. Confocal laser microscopy has made possible the precise spatial characterization of changes in intracellular $\mathrm{Ca}^{2+}$. This technique permits the optical slicing of myocytes in planes as thin as $500 \mathrm{~nm}$. Fluo-3AM-loaded ventricular myocytes were imaged with a Zeiss LSM-410 laser-scanning confocal microscope using the $488 \mathrm{~nm}$ line of an argon/krypton laser. An excitation dichroic mirror with a cutoff of $510 \mathrm{~nm}$ and a long-pass emission filter with a cutoff of $520 \mathrm{~nm}$ were used to detect Fluo-3AM fluorescence using a photomultiplier tube. Scanning optics scanned the excitation light over a sample in a raster fashion, building the image pixel by pixel. Two-dimensional confocal images were acquired by scanning an image of $100 \times 100$ pixels at the highest possible rate that still resulted in sufficient signal to noise. This procedure resulted in an image-acquisition rate of about 4 frames per second. Cells with detectable motion artifacts were excluded from the study. Sequences of digitized images were transferred to an SGI Indigo ${ }^{2}$ Extreme workstation (Silicon Graphics, Mountain View, Calif.) for off-line analysis by the ANALYZE image analysis system developed at the Mayo Clinic.

Calibration of the Fura-2 and Fluo-3 signals. In cells loaded with Fura-2AM, an estimate of the $\mathrm{Ca}^{2+}$ concentration $\left(\left[\mathrm{Ca}^{2+}\right]\right)$ was obtained according to the equa$\operatorname{tion}^{17,18}$ :

$$
\left[C a^{2+}\right]=\frac{R-R_{\min }}{R_{\max }-R} K_{d} \beta
$$

where $R$ is the fluorescence ratio recorded from the cell and $R_{\text {min }}$ and $R_{\max }$ represent the fluorescence ratio in the absence of $\mathrm{Ca}^{2+}$ (extracellular $\mathrm{Ca}^{2+}$ was removed and a 3 $\mathrm{mmol} / \mathrm{L}$ concentration of ethylene glycol-bis $(\beta$-amino- 
ethyl ether) $\mathrm{N}, \mathrm{N}, \mathrm{N}^{\prime}, \mathrm{N}^{\prime}$-tetraacetic acid [EGTA] added to the extracellular solution) and at high $\mathrm{Ca}^{2+}$ concentration $\left(\mathrm{CaCl}_{2} 3 \mathrm{mmol} / \mathrm{L}\right)$, respectively. $K_{d}$ is the $\mathrm{Ca}^{2+}$ dissociation constant of the dye $(236 \mathrm{nmol} / \mathrm{L})$, and $\beta$ the ratio of minimum to maximum fluorescence at $380 \mathrm{~nm} \cdot{ }^{17,18}$ So that $R_{\min }$ and $R_{\max }$ could be obtained, Fura-2AM-loaded cardiac cells were exposed to the calcium ionophore 4-bromo A-23187. So that contraction of permealized cells exposed to high concentrations of extracellular $\mathrm{Ca}^{2+}$ could be prevented, myocytes were pretreated with carbonyl cyanide-p-trifluoromethoxyphenylhydrazone (2 $\mu \mathrm{mol} / \mathrm{L}$ ) and 2,3-butaneodione monoxime (40 mmol $/ \mathrm{L}$ ). The intracellular $\mathrm{Ca}^{2+}$ concentration in quiescent ventricular myocytes estimated from Fura-2 AM-loaded cells was $81 \pm 10 \mathrm{nmol} / \mathrm{L}(n=21)$.

The increase in intracellular $\mathrm{Ca}^{2+}$ concentration as a function of Fluo-3 fluorescence was estimated by resolving the system of three equations, which include the expression for equilibrium $\mathrm{Ca}^{2+}$ concentration using the relative fraction of bound $\left(f_{C a}\right)$ and unbound $\left(f_{u}\right)$ Fluo-3 to $\mathrm{Ca}^{2+}$ :

$$
\left[\mathrm{Ca}^{2+}\right]=K_{d} \frac{f_{C a}}{f_{u}}
$$

where $K_{d}$ is dissociation constant of Fluo-3 (422 nmol/L) and $f_{C a}$ and $f_{u}$ relate to the total concentration of Fluo-3 by the relation:

$$
f_{C a}+f_{u}=f_{t}
$$

The relation between Fluo-3 intensity $(F)$ and the above parameters is given by:

$$
F=F_{\max } \frac{f_{C a}}{f_{t}}+F_{\min } \frac{f_{u}}{f_{t}}
$$

where $F_{\max }$ and $F_{\text {min }}$ are the maximum and minimum Fluo-3 fluorescence intensity. Resolving equations 1, 2, and 3 relatively to $\mathrm{Ca}^{2+}$ concentration produces the following equation:

$$
\left[C a^{2+}\right]=K_{d} \frac{F-F_{\min }}{F_{\max }-F}
$$

The estimate of cytosolic $\mathrm{Ca}^{2+}$ concentration is calculated taking into account the resting cytosolic $\mathrm{Ca}^{2+} \cdot$ concentration. ${ }^{19}$

Solutions and drugs. Tyrode solution had the following composition (in millimoles per liter) $\mathrm{NaCl}, 136.5 ; \mathrm{KCl}$, 5.4; $\mathrm{CaCl}_{2}, 1.8 ; \mathrm{MgCl}_{2}, 0.53$; glucose, 5.5; and HEPES$\mathrm{NaOH}, 5.5$ (pH 7.4). High $\mathrm{K}^{+} /$low $\mathrm{Cl}^{-}$contained (in millimoles per liter) taurine, 10; oxalic acid, 10; glutamic acid, $70 ; \mathrm{KCl}, 25 ; \mathrm{KH}_{2} \mathrm{PO}_{4}, 10$; glucose, 11; EGTA, 0.5; and HEPES-KOH, 10 ( $\mathrm{pH} 7.4)$. Hyperkalemic solutions were prepared by adding $\mathrm{K}^{+}$in a concentration of 10.6 $\mathrm{mmol} / \mathrm{L}$ to the Tyrode solution (final $\mathrm{K}^{+}$concentration: $16 \mathrm{mmol} / \mathrm{L}$ ). Hyperkalemic nominally $\mathrm{Ca}^{2+}$-free solution had the same composition as the hyperkalemic Tyrode solution with the exception that $\mathrm{Ca}^{2+}$ was omitted. Solutions containing a $16 \mathrm{mmol} / \mathrm{L}$ concentration of $\mathrm{MgCl}_{2}$ were prepared by adding $\mathrm{MgCl}_{2}(15.5 \mathrm{mmol} / \mathrm{L})$ to the Tyrode solution. Aprikalim, nicorandil, and glyburide were dissolved in $\mathrm{HCl}(1 \mathrm{~N})$, water, and DMSO, respectively, as concentrated stock solutions. All drugs were diluted to their final concentrations in the control Tyrode solution immediately before the experiment. Cardiomyocytes were incubated in Tyrode solution supplemented with aprikalim alone, nicorandil alone, or glyburide plus aprikalim for at least 10 minutes before the addition of a hyperkalemic challenge.

Statistics. Results are expressed as means \pm standard error. Significance was determined by Student's $t$ test, and $p<0.05$ was considered significant.

\section{Results}

Hyperkalemic solutions increase intracellular $\mathrm{Ca}^{2+}$ concentration in cardiomyocytes. Exposure of a single ventricular myocyte to a $16 \mathrm{mmol} / \mathrm{L}$ concentration of $\mathrm{K}^{+}$, a concentration present in commonly used cardioplegic solutions (e.g., St. Thomas' Hospital solution $\left.{ }^{1}\right)$, induced an increase in intracellular $\mathrm{Ca}^{2+}$ concentration (Fig. 1, A). Before addition of high $\mathrm{K}^{+}$-containing solution, intracellular $\mathrm{Ca}^{2+}$ concentration was estimated at $133 \pm 7 \mathrm{nmol} / \mathrm{L}(n=$ 74 ; Fig. $1, B)$, a value that is within the range for intracellular $\mathrm{Ca}^{2+}$ concentration measured during diastole. ${ }^{20-22} \mathrm{On}$ addition of a $16 \mathrm{mmol} / \mathrm{L}$ dose of $\mathrm{K}^{+}$, intracellular $\mathrm{Ca}^{2+}$ concentration increased to an estimated peak value of $441 \pm 32 \mathrm{nmol} / \mathrm{L}(n=$ $20 ; p<0.0001$; Fig. $1, B$ ). Thus a $16 \mathrm{mmol} / \mathrm{L}$ dose of $\mathrm{K}^{+}$induced a 3.3-fold increase in intracellular $\mathrm{Ca}^{2+}$ concentration as visualized by epifluorescent microscopy in single cardiac cells.

The elevation in intracellular $\mathrm{Ca}^{2+}$ concentration was abrupt after the $16 \mathrm{mmol} / \mathrm{L} \mathrm{K}^{+}$challenge, and maximal increases in intracellular $\mathrm{Ca}^{2+}$ concentration were reached within 15 to 20 seconds (Fig. 2, $B$ ). Elevation in intracellular $\mathrm{Ca}^{2+}$ concentration in the majority of cells was sustained at the peak level for more than 10 minutes. In some myocytes, intracellular $\mathrm{Ca}^{2+}$ concentration gradually declined from its peak value but remained above baseline (Fig. 2, $B)$. Thus solutions containing $\mathrm{K}^{+}$concentrations of $16 \mathrm{mmol} / \mathrm{L}$ increase intracellular $\mathrm{Ca}^{2+}$ concentration above diastolic levels for a prolonged period.

Within a myocyte, high $\mathrm{K}^{+}$-containing solutions induced an apparently nonhomogeneous spatial distribution of $\mathrm{Ca}^{2+}$, with the perinuclear and central regions showing higher fluorescence than regions around the sarcolemma (Fig. 1, $A$ ). This may indicate a predilection for higher increases in $\mathrm{Ca}^{2+}$ concentration in selected subcellular anatomic regions, or it could be due to contribution of out-offocus fluorescence coming from different optical planes. 


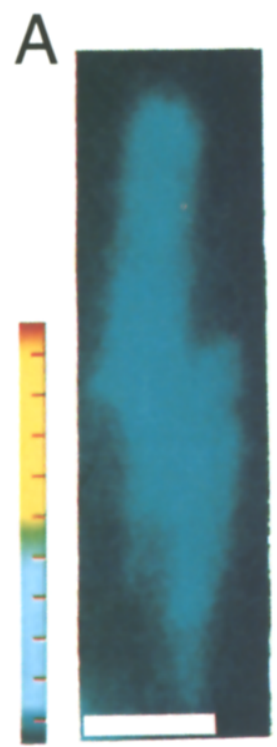

0

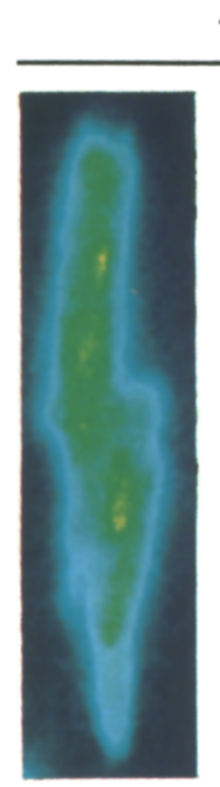

10
$16 \mathrm{mM} \mathrm{K}^{+}$

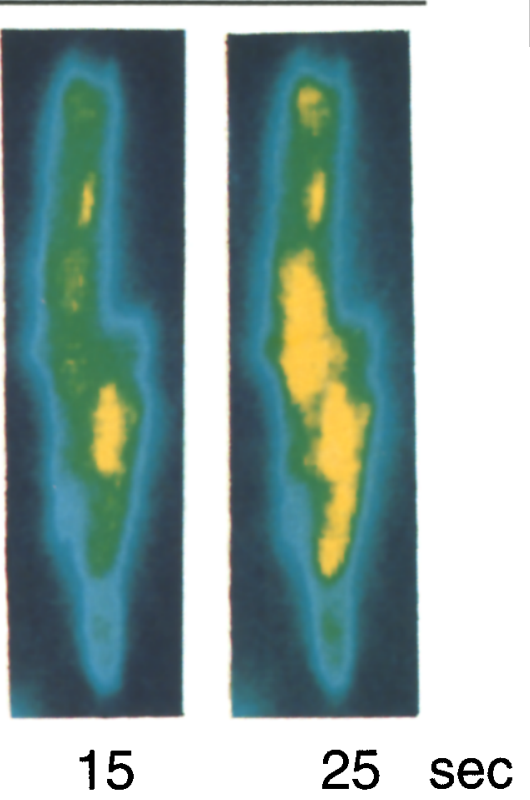

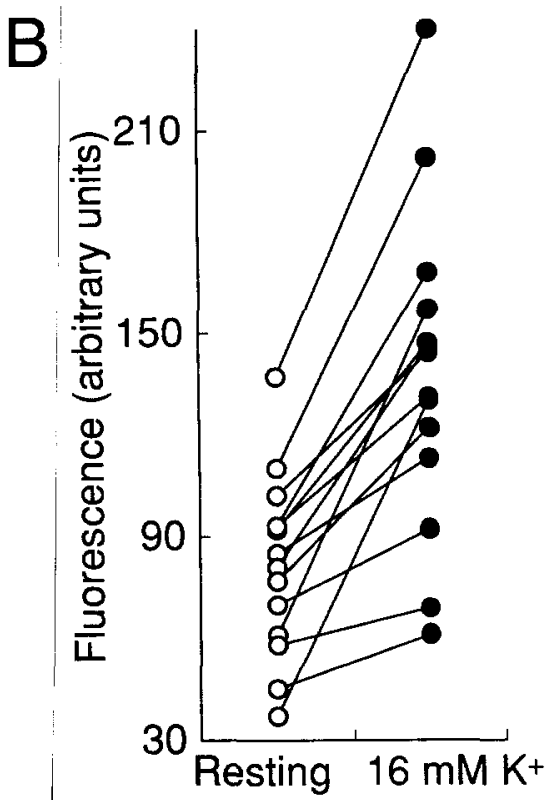

Fig. 1. Increase in intracellular $\mathrm{Ca}^{2+}$ induced by a hyperkalemic solution in cardiac cells. Ventricular myocytes, loaded with the $\mathrm{Ca}^{2+}$-sensitive fluorescent probe, Fluo-3, were imaged by epifluorescent digital imaging. A, A series of four images obtained before ( 0 seconds) and 10, 15 and 25 seconds after raising the extracellular concentration of $\mathrm{K}^{+}$to $16 \mathrm{mmol} / \mathrm{L}$. Horizontal bar corresponds to $20 \mu \mathrm{m}$. Vertical bar represents the Fluo-3 fluorescence displayed in pseudocolors with a continuous rainbow pattern. B, Fluo-3 fluorescence before ( 0 seconds; open circles) and 35 seconds after addition of $\mathrm{K}^{+}$(closed circles) recorded from ventricular myocytes obtained from 13 hearts. An estimate of the average change in intracellular $\mathrm{Ca}^{2+}$ concentration is given in the text.

To obtain a more precise spatial resolution of changes in intracellular $\mathrm{Ca}^{2+}$, we used laser scanning confocal microscopy to record fluorescence from a single optical plane, thus effectively removing contributions of out-of-focus fluorescence. In 16 myocytes, intracellular $\mathrm{Ca}^{2+}$ concentration was homogeneous before exposure (estimated average concentration $121 \pm 15 \mathrm{nmol} / \mathrm{L}$ ) and increased by a factor of 3.5 (to an estimated concentration of $425 \pm$ $40 \mathrm{nmol} / \mathrm{L}$ ) after exposure of a cardiac cell to a 16 mmol/L concentration of $\mathrm{K}^{+}$(Fig. $2, A$ ). The elevation in intracellular $\mathrm{Ca}^{2+}$ concentration was not uniform, with localized regions of higher concentration surrounded by areas of lower concentration (Fig. 2, A). Spatial analysis did not reveal a predilection for higher increases in fluorescence in the central region of the cell versus the perisarcolemmal area. In several myocytes, temporal analysis revealed an oscillatory pattern in the elevation of fluorescence (not illustrated). Thus scanning laser confocal microscopy confirms that changes in fluorescence induced by high $\mathrm{K}^{+}$-containing solutions were related to nonhomogeneous elevation in intracellular $\mathrm{Ca}^{2+}$ concentration.

Omission of extracellular $\mathrm{Ca}^{2+}$ does not prevent hyperkalemic solutions from inducing intracellular $\mathrm{Ca}^{2+}$ loading. Extracellular $\mathrm{Ca}^{2+}$ has been omitted from some cardioplegic solutions (e.g., Bretschneider solution) with the expectation that this modification will prevent intracellular $\mathrm{Ca}^{2+}$ loading. ${ }^{1} \mathrm{To}$ determine whether removal of extracellular $\mathrm{Ca}^{2+}$ prevents changes in intracellular $\mathrm{Ca}^{2+}$ concentration, we exposed single myocytes to hyperkalemic, nominally $\mathrm{Ca}^{2+}$-free solutions. As depicted in Fig. 3, a $16 \mathrm{mmol} / \mathrm{L}$ concentration of $\mathrm{K}^{+}$induced an increase in intracellular $\mathrm{Ca}^{2+}$ concentration, under this condition. When cardiac myocytes were exposed to hyperkalemic nominally $\mathrm{Ca}^{2+}$-free solutions, intracellular $\mathrm{Ca}^{2+}$ concentration, was increased on average to $396 \pm 50 \mathrm{nmol} / \mathrm{L}(n=12)$, a concentration not significantly different from that obtained in solutions containing a $1.8 \mathrm{mmol} / \mathrm{L}$ concentration of extracellular $\mathrm{Ca}^{2+}$. Thus omission of extracellular $\mathrm{Ca}^{2+}$ from hyperkalemic solutions apparently does 


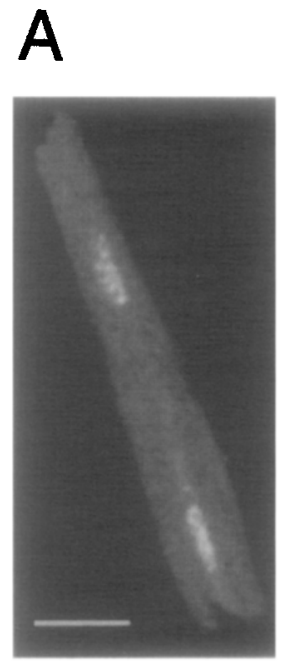

0

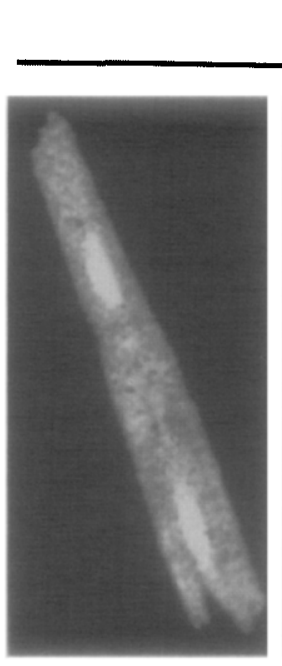

11

\section{$16 \mathrm{mM} \mathrm{K}^{+}$}

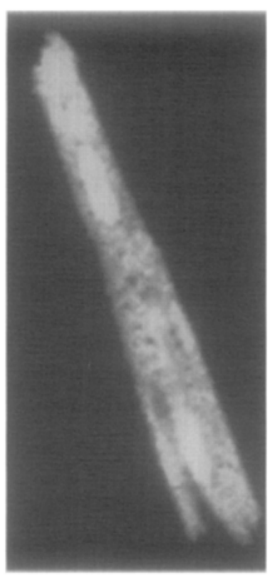

35

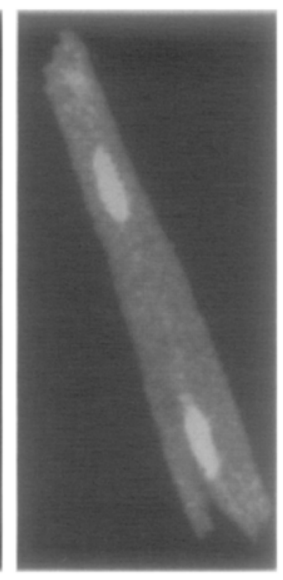

$121 \mathrm{sec}$

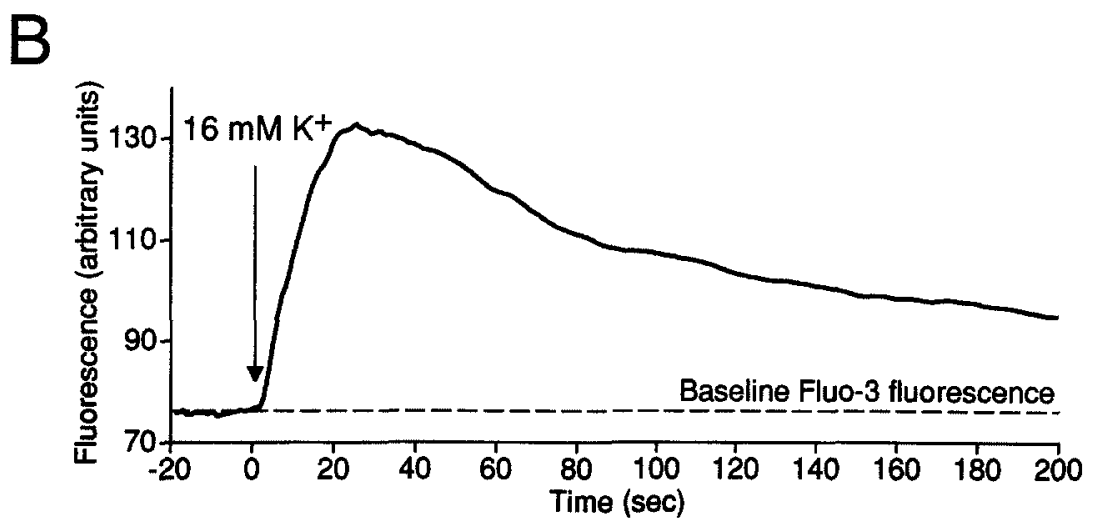

Fig. 2. Spatiotemporal distribution of intracellular $\mathrm{Ca}^{2+}$ revealed by laser confocal microscopy. Laser confocal microscopy was used to optically section a binucleated, Fluo-3 loaded, cardiomyocyte. A, Series of confocal images obtained before ( 0 seconds) and 11,35, and 121 seconds after raising the extracellular concentration of $\mathrm{K}^{+}$to $16 \mathrm{mmol} / \mathrm{L}$. At time 0 seconds, the baseline cytosolic fluorescence of the myocyte was low. At time 11 seconds, a nonhomogeneous increase in fluorescence occurred. At time 35 seconds, fluorescence continued to increase, making more evident the nonuniform pattern of $\mathrm{Ca}^{2+}$ elevation. At time 121 seconds, fluorescence decreased from its peak level but remained above baseline. Note that at all time points the fluorescence of the nuclei was higher than that of the cytosol. Horizontal bar represents 20 $\mu \mathrm{m}$. B, Time course of changes in the average Fluo- 3 fluorescence induced by raising the concentration of $\mathrm{K}^{+}$in the myocyte depicted in $\mathrm{A}$. Intracellular $\mathrm{Ca}^{2+}$ concentration increased from an estimated $156 \mathrm{nmol} / \mathrm{L}$ (at 0 seconds) to $410 \mathrm{nmol} / \mathrm{L}$ (at 35 seconds) and $249 \mathrm{nmol} / \mathrm{L}$ (at 121 seconds).

not prevent elevation in intracellular $\mathrm{Ca}^{2+}$ concentration.

Extracellular $\mathrm{Mg}^{2+}$ does not prevent hyperkalemic solutions from increasing intracellular $\mathrm{Ca}^{2+}$. Although it has been suggested that addition of a $16 \mathrm{mmol} / \mathrm{L}$ concentration of $\mathrm{Mg}^{2+}$ to cardioplegic solutions has a protective effect on the myocardi$\mathrm{um},{ }^{12}$ it is not known whether elevating extracellular $\mathrm{Mg}^{2+}$ prevents changes in intracellular $\mathrm{Ca}^{2+}$ induced by hyperkalemic solutions. Exposure of cardiac cells to solutions containing $16 \mathrm{mmol} / \mathrm{L}$ concentrations of $\mathrm{K}^{+}$and $\mathrm{Mg}^{2+}$ induced an increase in intracellular $\mathrm{Ca}^{2+}$ concentration (Fig. 4, A). Despite the presence of $\mathrm{Mg}^{2+}, 16 \mathrm{mmol} / \mathrm{L}$, elevation in intracellular $\mathrm{Ca}^{2+}$ concentration was sustained (Fig. 4, B) and occasionally fluctuated, reffecting oscillations in intracellular $\mathrm{Ca}^{2+}$ concentration (Fig. 4, B). These oscillations may 


\section{$16 \mathrm{mM} \mathrm{K}^{+}$ nominally $\mathrm{Ca}^{2+}$ free}

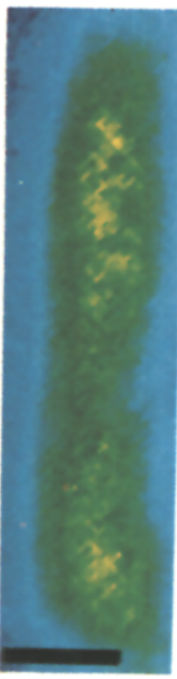

0

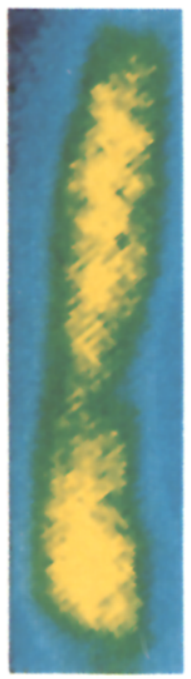

15

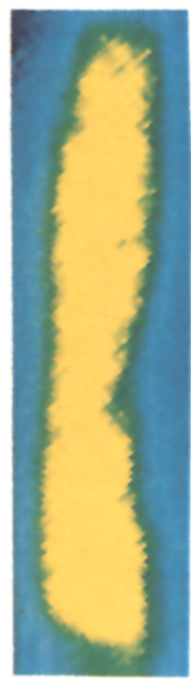

30

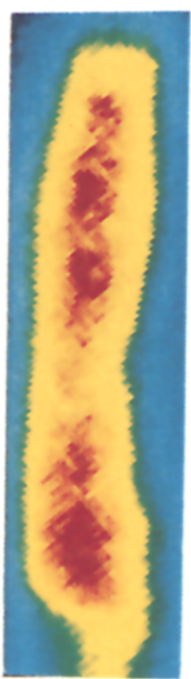

$45 \mathrm{sec}$

Fig. 3. Excluding extracellular $\mathrm{Ca}^{2+}$ does not prevent intracellular $\mathrm{Ca}^{2+}$ increase. A series of four epifluorescent images recorded from a ventricular myocyte incubated in nominally free $\mathrm{Ca}^{2+}$ solution and exposed to $\mathrm{K}^{+}$ in a concentration of $16 \mathrm{mmol} / \mathrm{L}$ shows a time-dependent increase in Fluo-3 fluorescence from a low resting level ( 0 seconds) before addition of $\mathrm{K}^{+}$to higher levels (at $15,30,45$ seconds) after addition of $\mathrm{K}^{+}$. Horizontal bar corresponds to $25 \mu \mathrm{m}$. Vertical bar represents the Fluo-3 fluorescence displayed in pseudocolors.

reflect continuous $\mathrm{Ca}^{2+}$ release from and reuptake into intracellular stores. In eight myocytes (Fig. 4,C), the average elevation of intracellular $\mathrm{Ca}^{2+}$ concentration was to $463 \pm 28 \mathrm{nmol} / \mathrm{L}$, a value not significantly different from that obtained in low extracellular $\mathrm{Mg}^{2+}$. Thus supplementation of hyperkalemic solutions with $\mathrm{Mg}^{2+}, 16 \mathrm{mmol} / \mathrm{L}$, a concentration used in the St. Thomas' Hospital II cardioplegic solution, does not prevent the increase in intracellular $\mathrm{Ca}^{2+}$ concentration induced by a hyperkalemic challenge in ventricular myocytes.

Potassium channel opening drugs prevent hyperkalemic solutions from inducing an increase in intracellular $\mathrm{Ca}^{2+}$. Potassium channel opening drugs, such as aprikalim and nicorandil, protect the myocardium from ischemic insults and modulate intracellular $\mathrm{Ca}^{2+}$ concentration in smooth muscle cells. ${ }^{22-25}$ Cardiomyocytes were pretreated with aprikalim (a thioformamide) or nicorandil (a nicotinamide) before being exposed to the $16 \mathrm{mmol} / \mathrm{L}$ $\mathrm{K}^{+}$solution. Aprikalim $(40 \mu \mathrm{mol} / \mathrm{L})$ or nicorandil $(300 \mu \mathrm{mol} / \mathrm{L})$ prevented $\mathrm{K}^{+} 16 \mathrm{mmol} / \mathrm{L}$ from inducing an increase in intracellular $\mathrm{Ca}^{2+}$ concentration in all 21 myocytes so tested (Fig. 5). The intracellular $\mathrm{Ca}^{2+}$ concentrations after addition of $\mathrm{K}^{+} 16$ $\mathrm{mmol} / \mathrm{L}$ were $115 \pm 7 \mathrm{nmol} / \mathrm{L}(n=10)$ and $135 \pm 4$ $\mathrm{nmol} / \mathrm{L}(n=11)$ in aprikalim- and nicorandiltreated myocytes, respectively. Thus potassium channel opening drugs protect myocytes from hyperkalemia-induced intracellular $\mathrm{Ca}^{2+}$ loading.

Glyburide antagonizes the ability of a potassium channel opening drug to prevent hyperkalemiainduced elevation in intracellular $\mathrm{Ca}^{2+}$. Potassium channel opening drugs activate myocardial ATPsensitive $\mathrm{K}^{+}$channels. $^{26,27}$ Cardiac cells were therefore treated with glyburide $(6 \mu \mathrm{mol} / \mathrm{L})$, a selective blocker of ATP-dependent $\mathrm{K}^{+}$chan- 


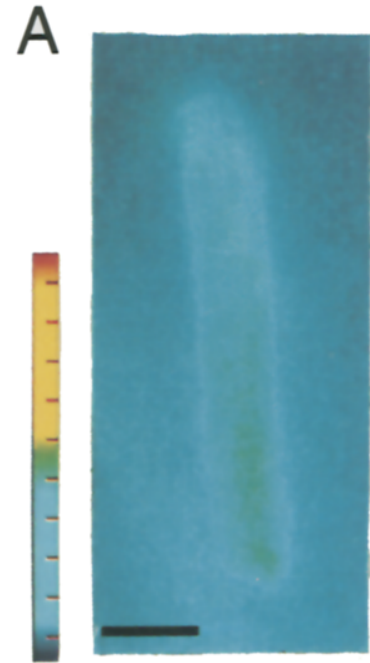

0

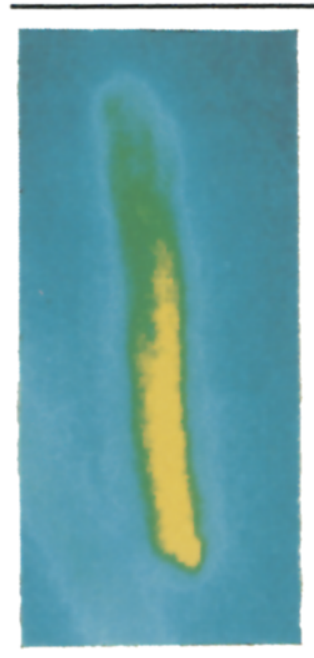

8

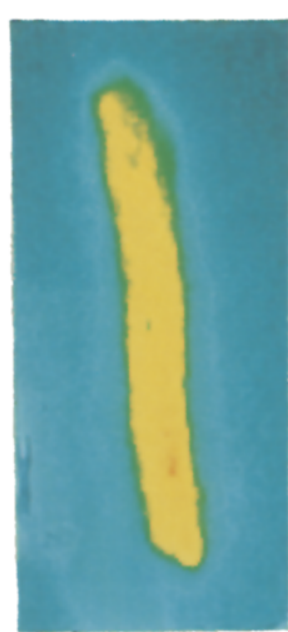

16

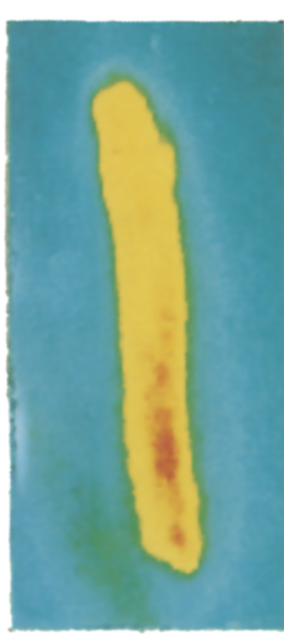

24 $\sec$
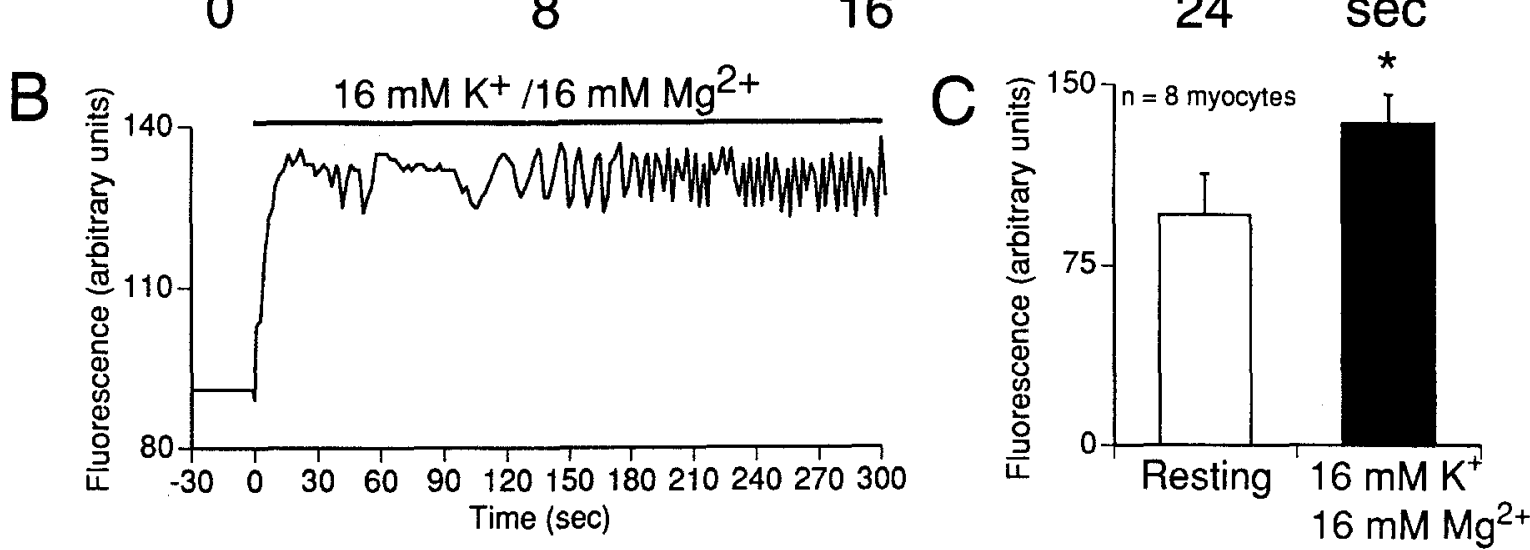

Fig. 4. Supplementing hyperkalemic solutions with $\mathrm{MgCl}_{2}, 16 \mathrm{mmol} / \mathrm{L}$, does not prevent intracellular $\mathrm{Ca}^{2+}$ increase. A, A series of four epifluorescent images obtained from a single cardiac myocyte before $(0$ seconds) and 8, 16, and 24 seconds after exposure to $16 \mathrm{mmol} / \mathrm{L}$ doses of $\mathrm{KCl}$ and $\mathrm{MgCl}_{2}$. Horizontal bar corresponds to $15 \mu \mathrm{m}$. Vertical bar represents the Fluo-3 fluorescence displayed in pseudocolors. B, Time course of relative changes in Fluo-3 fluorescence induced by $16 \mathrm{mmol} / \mathrm{L}$ doses of $\mathrm{KCl}$ and $\mathrm{MgCl}_{2}$ in the cell depicted in A. C, Average fluorescence at rest and 35 seconds after exposure of eight ventricular myocytes to $16 \mathrm{mmol} / \mathrm{L}$ doses of $\mathrm{KCl}$ and $\mathrm{MgCl}_{2}$. Star corresponds to $p<0.01$. An estimate of changes in the intracellular $\mathrm{Ca}^{2+}$ concentration is given in the text.

nels. ${ }^{28,29}$ In glyburide-treated myocytes, aprikalim was unable to prevent an elevation in intracellular $\mathrm{Ca}^{2+}$ induced by $\mathrm{K}^{+} 16 \mathrm{mmol} / \mathrm{L}$ (Fig. 6). In glyburide- and aprikalim-treated myocytes, intracellular $\mathrm{Ca}^{2+}$ concentration was $150 \pm 6 \mathrm{nmol} / \mathrm{L}$ before and $422 \pm 49 \mathrm{nmol} / \mathrm{L}$ after $\mathrm{K}^{+} 16 \mathrm{mmol} / \mathrm{L}$ was added $(n=9)$. These results suggest that potassium channel openers prevent high $\mathrm{K}^{+}$from increasing intracellular $\mathrm{Ca}^{2+}$ through a glyburidesensitive mechanism.

\section{Discussion}

The present study demonstrates that hyperkalemic solutions elevate intracellular $\mathrm{Ca}^{2+}$ concentration in isolated ventricular myocytes. These results extend previously obtained findings from multicellular heart preparations and cardiac cell suspensions ${ }^{9,10}$ and provide direct evidence, at the single cell level, that hyperkalemic solutions such as the one used in cardioplegia can increase intracellular $\mathrm{Ca}^{2+}$ concentration. An increase in intracellular $\mathrm{Ca}^{2+}$ concentration could 


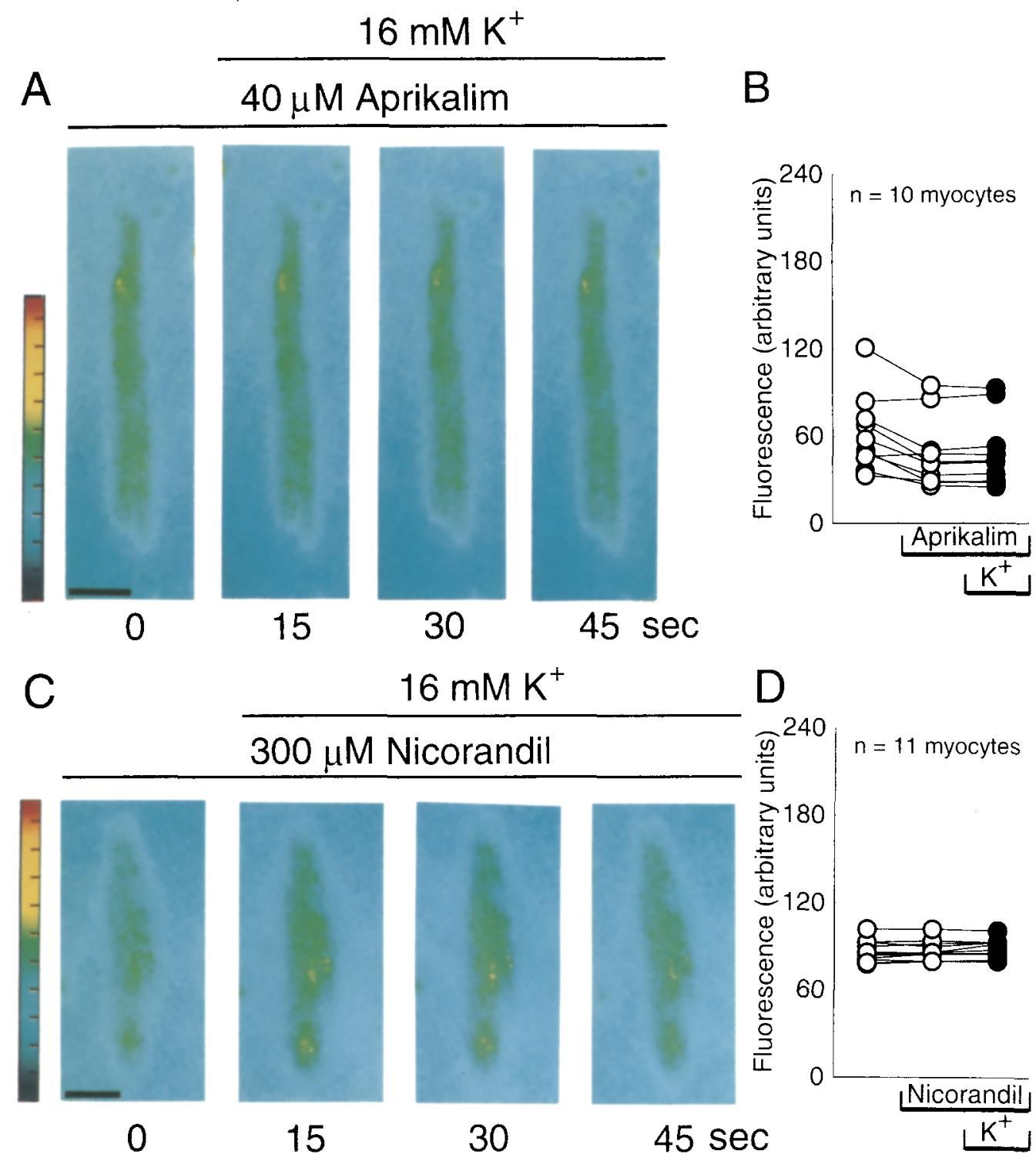

Fig. 5. Supplementing hyperkalemic solutions with potassium channel openers prevents intracellular $\mathrm{Ca}^{2+}$ increase. A, A series of epifluorescent images obtained from a single Fluo-3AM-loaded myocyte pretreated for 10 minutes with aprikalim and imaged before ( 0 seconds) and 15, 30, and 45 seconds after exposure to $\mathrm{K}^{+}, 16 \mathrm{mmol} / \mathrm{L}$, in the continuous presence of aprikalim. B, Fluorescence recorded from 10 myocytes under three conditions. Left, open circles: baseline; right, open circles: in aprikalim $(40 \mu \mathrm{mol} / \mathrm{L})$; closed circles: in aprikalim and $\mathbf{K}^{+}, 16 \mathrm{mmol} / \mathrm{L}$. $\mathbf{C}$, A series of epifluorescent images of a single Fluo-3AM-loaded myocyte pretreated for 10 minutes with nicorandil and imaged before ( 0 seconds) and 15, 30, and 45 seconds after exposure to $16 \mathrm{mmol} / \mathrm{L} \mathrm{K}^{+}$, in the continuous presence of nicorandil. D, Fluorescence recorded from 11 myocytes under three conditions. Left, open circles: baseline; right, open circles: in nicorandil ( $300 \mu \mathrm{mol} / \mathrm{L})$; closed circles: in nicorandil and $16 \mathrm{mmol} / \mathrm{L} \mathrm{K}^{+}$. An estimate of the changes in intracellular $\mathrm{Ca}^{2+}$ concentration is given in the text. Horizontal bar corresponds to $10 \mu \mathrm{m}$ in $\mathbf{A}$ and $\mathbf{C}$.

potentially lead to cellular dysfunction and contribute to myocardial damage, as previously described in various pathophysiologic conditions associated with a hyperkalemic challenge, such as cardioplegic arrest. ${ }^{5}$
The observed elevation in cytosolic $\mathrm{Ca}^{2+}$ was modest and did not lead to apparent shortening of the hyperkalemia-challenged cardiomyocyte. Yet moderate elevation of cytosolic $\mathrm{Ca}^{2+}$ has been related to signaling information independent of con- 


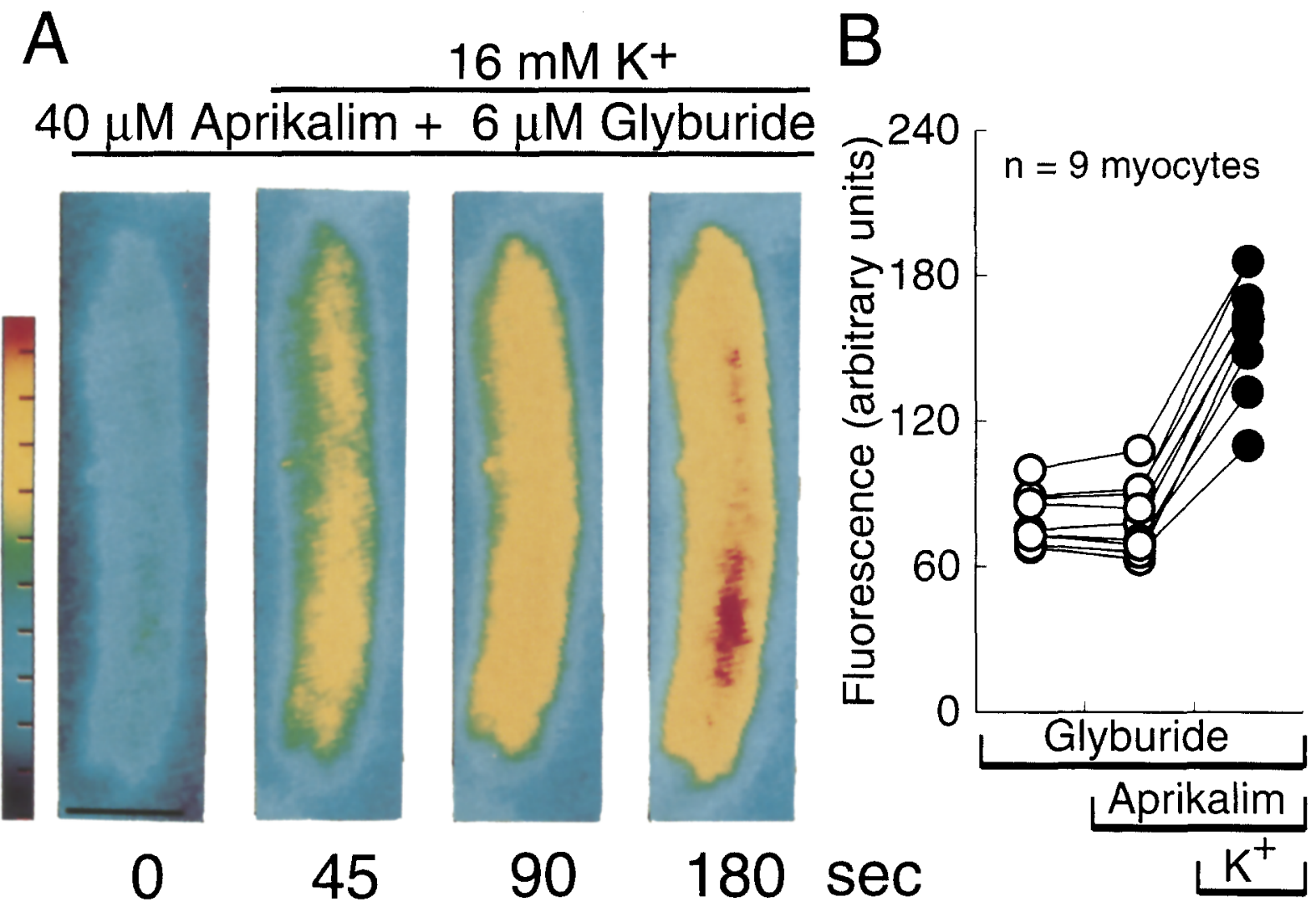

Fig. 6. A selective inhibitor of ATP-sensitive $\mathrm{K}^{+}$channels antagonizes the ability of a potassium channel opener to prevent hyperkalemia-induced intracellular $\mathrm{Ca}^{2+}$ increase. A, A serie of four epifluorescent images obtained from a myocyte pretreated with glyburide plus aprikalim before ( 0 seconds) and 45, 90, 180 seconds after addition exposure to $\mathrm{K}^{+}, 16 \mathrm{mmol} / \mathrm{L}$. B, Summary graph depicts Fluo-3 fluorescence recorded from nine myocytes. Circles correspond to fluorescence recorded in individual myocytes under three different conditions. Left, open circles: glyburide $(6 \mu \mathrm{mol} / \mathrm{L}) ;$ right, open circles: glyburide $(6 \mu \mathrm{mol} / \mathrm{L})$ plus aprikalim $(40 \mu \mathrm{mol} / \mathrm{L})$; closed circles: glyburide $(6 \mu \mathrm{mol} / \mathrm{L})$ plus aprikalim $(40 \mu \mathrm{mol} / \mathrm{L})$ and $\mathrm{K}^{+}(16$ $\mathrm{mmol} / \mathrm{L})$. An estimate of the changes in intracellular $\mathrm{Ca}^{2+}$ concentration is given in the text.

traction. ${ }^{30}$ Because during cardioplegia the myocardium is under conditions of global ischemia with a lower production of ATP when compared with normal conditions, a modest elevation in intracellular $\mathrm{Ca}^{2+}$ could represent an additional load on the energy-dependent $\mathrm{Ca}^{2+}$-homeostatic mechanisms and could predispose cardiac cells to reperfusion injury and diastolic dysfunction. ${ }^{4,10}$

The mechanism responsible for the hyperkalemia-induced increase in intracellular $\mathrm{Ca}^{2+}$ concentration is most likely related to membrane depolarization, ${ }^{20}$ because high $\mathrm{K}^{+}$-containing solutions depolarize by at least $-30 \mathrm{mV}$ the cell membrane of ventricular myocytes. ${ }^{31}$ Membrane depolarization promotes $\mathrm{Ca}^{2+}$ influx through voltage-dependent $\mathrm{Ca}^{2+}$ channels. $\mathrm{Ca}^{2+}$ influx, in turn, induces release of $\mathrm{Ca}^{2+}$ from intracellular stores. ${ }^{32}$ Additional membrane potential-sensitive processes that regulate intracellular $\mathrm{Ca}^{2+}$ homeostasis may also participate in the hyperkalemia-induced increase in intracellular $\mathrm{Ca}^{2+} .33$

$\mathrm{Ca}^{2+}$ has been omitted from cardioplegic solutions to limit $\mathrm{Ca}^{2+}$ overload during surgical ischemia. ${ }^{34}$ However, our results with nominally $\mathrm{Ca}^{2+}$ free solutions indicate that omission of $\mathrm{Ca}^{2+}$ from a hyperkalemic solution, as practiced with "acalcemic" cardioplegia, does not necessarily prevent intracellular increase of $\mathrm{Ca}^{2+}$. This finding may suggest that in nominally $\mathrm{Ca}^{2+}$-free solutions a sufficient concentration of extracellular $\mathrm{Ca}^{2+}$ still remains in the extracellular space and could enter during membrane depolarization to trigger release of $\mathrm{Ca}^{2+}$ from intracellular stores, leading to increase in intracellular $\mathrm{Ca}^{2+}$ concentration. Indeed, the 
peak value of $\mathrm{Ca}^{2+}$ current at a given membrane potential is dependent on the reversal of $\mathrm{Ca}^{2+}$ potential which, on the basis of the Nernst equation, will not dramatically change even after reduction of extracellular $\mathrm{Ca}^{2+}$ to a value 10 to 20 times lower than control external $\mathrm{Ca}^{2+}$ concentrations. Contamination of such magnitude may be present in "acalcemic" solutions. In compromised myocytes, elevation in intracellular $\mathrm{Ca}^{2+}$ concentration has been ascribed to mechanisms independent of $\mathrm{Ca}^{2+}$ influx through $\mathrm{Ca}^{2+}$ channels. ${ }^{35}$ Further studies are required to elucidate the source of $\mathrm{Ca}^{2+}$ leading to $\mathrm{Ca}^{2+}$ loading. That exposure of the heart to "acalcemic" solutions did not prevent $\mathrm{Ca}^{2+}$ loading is consistent with the clinical evidence showing that "acalcemic" cardioplegic solutions are not necessarily more protective than conventional cardioplegic solutions. $^{36}$

In the myocardium, $\mathrm{Mg}^{2+}$ has been shown to act as a physiologic $\mathrm{Ca}^{2+}$ antagonist and is required as a cofactor to nucleotides for energy transfer reaction and transport processes. ${ }^{37}$ High concentrations of $\mathrm{Mg}^{2+}$ in hyperkalemic cardioplegic solutions may have a beneficial effect by (1) antagonizing the unwanted effects of elevated intracellular $\mathrm{Ca}^{2+}, 9,38$

(2) reducing the leakage of myocardial enzymes, and

(3) preventing ATP depletion. The present study shows that adding a $16 \mathrm{mmol} / \mathrm{L}$ concentration of $\mathrm{Mg}^{2+}$ to high $\mathrm{K}^{+}$solutions did not prevent the increase in intracellular $\mathrm{Ca}^{2+}$. This finding does not necessarily rule out a protective effect of $\mathrm{Mg}^{2+}$ on the myocardium during cardioplegic arrest independently from an increase in intracellular $\mathrm{Ca}^{2+}$ concentration. ${ }^{13}$

The major finding of the present study is that potassium channel opening drugs effectively prevent high $\mathrm{K}^{+}$solutions $(16 \mathrm{mmol} / \mathrm{L})$ from increasing intracellular $\mathrm{Ca}^{2+}$ concentration in cardiac cells. The precise mechanism of action of potassium channel openers responsible for this effect is not known. Possible mechanisms could relate to the ability of a potassium channel opener to keep the membrane potential at a more negative value when the extracellular $\mathrm{K}^{+}$concentration is less than $20 \mathrm{mmol} / \mathrm{L} .^{23}$ It has been reported that a potassium channel opener shifts the resting membrane potential of muscle cells by approximately $15 \mathrm{mV}$ to the negative direction at an extracellular concentration of $\mathrm{K}^{+}$ close to $16 \mathrm{mmol} / \mathrm{L}^{23}$ Previously, we have demonstrated, at the whole cell and single channel level using the patch-clamp technique, that the potassium channel opening drugs used in this study, aprikalim and nicorandil, selectively activate ATP-sensitive $\mathrm{K}^{+}$channels in cardiac cells, ${ }^{26,27,39}$ In vascular smooth muscle, $\mathrm{K}^{+}$channel openers appear to prevent hyperkalemic solution-induced increase in intracellular $\mathrm{Ca}^{2+}$ by keeping the membrane potential above the gating level of voltage-sensitive $\mathrm{Ca}^{2+}$ channels and preventing $\mathrm{Ca}^{2+}$ entry. ${ }^{23}$ In view of the voltage-dependence of cardiac $\mathrm{Ca}^{2+}$ channels, a similar mechanism could be involved in underlying the reduction in $\mathrm{Ca}^{2+}$ influx during depolarization. At higher extracellular $\mathrm{K}^{+}$concentrations (above 20 $\mathrm{mmol} / \mathrm{L}$ ), potassium channel openers will still open $\mathrm{K}^{+}$channels; yet this effect will not translate into a change in the value of the resting membrane potential, since net $\mathrm{K}^{+}$efflux under these conditions is much less pronounced. ${ }^{23}$ Indeed, at an extracellular $\mathrm{K}^{+}$concentration of $32 \mathrm{mmol} / \mathrm{L}$, we have found no protective effect of potassium channel openers on hyperkalemia-induced $\mathrm{Ca}^{2+}$ loading in cardiac cells. ${ }^{40}$ Also, potassium channel openers have been proposed to regulate intracellular $\mathrm{Ca}^{2+}$ handling in addition to their effect on the cellular membrane. ${ }^{22,23}$ Thus several mechanism(s) may underlie the effect of potassium channel openers on preventing hyperkalemia-induced $\mathrm{Ca}^{2+}$ loading in cardiac cells.

In various models of ischemia, opening of ATPsensitive $\mathrm{K}^{+}$channels has been associated with cardioprotection. ${ }^{25,41,42}$ In whole heart preparations and intact animals, aprikalim protected the myocardium from ischemic damage through a glyburide-sensitive mechanism. ${ }^{25,42,43}$ The present finding, that glyburide, a selective blocker of ATPsensitive $\mathrm{K}^{+}$channels ${ }^{28,29}$ prevented the protective effect of aprikalim on hyperkalemia-induced intracellular $\mathrm{Ca}^{2+}$ increase suggests that opening of ATP-sensitive $\mathrm{K}^{+}$channels may play a role in protecting cardiac cells from $\mathrm{Ca}^{2+}$ loading.

Recently, it has been shown that potassium channel openers accelerate the recovery of myocardial function and preserve intracellular adenosine triphosphate content and mitochondrial structure after global surgical ischemia. ${ }^{43-45}$ Under these conditions, potassium channel openers may be superior to calcium channel blockers that do not affect postischemic recovery. ${ }^{46}$ However, the clinical use of potassium channel openers should be considered with caution because of the systemic effects, such as vasodilation, and the limited clinical experience with this novel family of therapeutics. ${ }^{47}$ Although improved tissue selectivity of this class of compounds is an important prerequisite for the wide clinical use of 
potassium channel openers, the experimental evidence that these agents could be beneficial as a supplement to hyperkalemic cardioplegic solutions during cardiopulmonary bypass are encouraging. ${ }^{43-45}$ The findings presented herein further support such a notion because they indicate that in single cardiac cells, potassium channel openers could alleviate potentially deleterious increases in intracellular $\mathrm{Ca}^{2+}$ concentration associated with hyperkalemic challenges.

We gratefully acknowledge the technical assistance of James E. Tarara and Teresa J. Halsey with the epifluorescent imaging system and the assistance of Dr. Ray Ghanbari with confocal microscopy.

\section{REFERENCES}

1. Hearse DG, Braimbridge MV, Jynge P. Protection of the ischemic myocardium. Cardioplegia. New York: Raven, 1981.

2. Engelman RM, Levitsky S. A textbook for cardioplegia for difficult clinical problems. Mount Kisco (NY): Futura, 1992.

3. Kay HR, Levine FH, Fallon JT, Grotte GJ, Butchart EG, Rao S, et al. Effect of cross-clamp time, temperature, and cardioplegic agents on myocardial function after induced arrest. J Thorac Cardiovasc Surg 1978;76:591-9.

4. Cheung JY, Bonventre JV, Malis CD, Leaf A. Calcium and ischemic injury. N Engl J Med 1986;314:1670-6.

5. Nayler WG, Panagiotopoulos S, Elz JS, Daly MJ. Calcium mediated damage during post-ischemic reperfusion. J Mol Cell Cardiol 1988;20:41-54.

6. Cooley DA, Reul GJ, Wukasch DC. Ischemic contracture of the heart: "stone heart." Am J Cardiol 1972;29:575-7.

7. Kloner RA, Przyklenk K, Kay GL. Clinical evidence for stunned myocardium after coronary artery bypass surgery. $\mathbf{J}$ Card Surg 1994;9:397-402.

8. McKenney PA, Apstein CS, Mendes LA, Connelly GP, Aldea GC, Shemin RJ, et al. Increased left ventricular diastolic chamber stiffness immediately after coronary artery bypass surgery. J Am Coll Cardiol 1994;24:1189-94.

9. Cyran SE, Ditty SE, Baylen BG, Cheung J, LaNoue KF. Developmental differences in the response of cytosolic free calcium to potassium depolarization and cardioplegia in ventricular myocytes. J Mol Cell Cardiol 1992;24:1167-77.

10. McCully JD, Tsukube T, Ataka K, Krukenkamp IB, Feinberg $\mathrm{H}$, Levitsky S. Myocardial cytosolic calcium accumulation during ischemia/reperfusion: the effects of aging and cardioplegia. J Card Surg 1994;9:449-52.

11. Edwards G, Weston A. The pharmacology of ATP-sensitive potassium channels. Annu Rev Pharmacol Toxicol 1993;33: 597-637.

12. Hearse DJ, Steward DA, Braimbridge MV. Myocardial protection during ischemic cardiac arrest: the importance of magnesium in cardioplegic infusates. J Thorac Cardiovasc Surg 1978;75:877-85.

13. Geffin GA, Love TR, Hendren WG, Torchiana DF, Titus JS, Redonnett BE, et al. The effects of calcium and magnesium in hyperkalemic cardioplegic solutions on myocardial preservation. J Thorac Cardiovasc Surg 1989;98:239-50.

14. Reynolds TR, Geffin GA, Titus JS, O'Keefe DD, Daggett WM. Myocardial preservation related to magnesium content of hyperkalemic cardioplegic solutions at $8^{\circ} \mathrm{C}$. Ann Thorac Surg 1989;47:907-13.

15. Terzic A, Findlay I, Hosoya Y, Kurachi Y. Dualistic behavior of ATP-sensitive $\mathrm{K}^{+}$channel toward intracellular nucleoside diphosphates. Neuron 1994;12:1049-58.

16. Minta A, Kao AJPY, Tsien RY. Fluorescent indicators for cytosolic calcium based on rhodamine and fluoresceine chromophores. J Biol Chem 1989;264:8171-8.

17. Grynkiewicz G, Poenie M, Tsien RY. A new generation of $\mathrm{Ca}^{2+}$ indicators with greatly improved fluorescence properties. J Biol Chem 1985;260:3440-50.

18. Williams DA. Quantitative intracellular calcium imaging with laser-scanning confocal microscopy. Cell Calcium 1990;11: 589-97.

19. Xu J, Tashjian A. Cyclic-ADP-ribose-induced calcium release in sea urchin egg homogenates is a cooperative process. Biochemistry 1995;34:2815-8.

20. Powell T, Tatham PER, Twist VW. Cytosolic free calcium measured by Quin2 fluorescence in isolated ventricular myocytes at rest and during potassium-depolarization. Biochem Biophys Res Commun 1984;122:1012-20.

21. Wier WG, Cannell MB, Berlin JR, Marban E, Lederer WJ. Cellular and subcellular heterogeneity of $\left[\mathrm{Ca}^{2+}\right] \mathrm{i}$ in single heart cells revealed by Fura-2. Science 1987;235:325-8.

22. Yanagisawa T, Teshigawara T, Taira N. Cytoplasmic calcium and the relaxation of canine coronary arterial smooth muscle produced by cromakalim, pinacidil and nicorandil. $\mathrm{Br} \mathrm{J}$ Pharmacol 1990;101:157-65.

23. Quast $\mathrm{U}$. Do the $\mathrm{K}^{+}$channel openers relax smooth muscle by opening $\mathrm{K}^{+}$channels? Trends Pharmacol Sci 1993;14:332-7.

24. Criddle DN, Greenwood IA, Weston AH. Levcromakaliminduced modulation of membrane potassium currents, intracellular calcium and mechanical activity in rat mesenteric artery. Naunyn Schmiedebergs Arch Pharmacol 1994;349: 422-30.

25. Grover G. 1994. Protective effects of ATP sensitive potassium channel openers in models of myocardial ischemia. Cardiovasc Res 1994;28:778-82.

26. Shen WK, Tung RT, Machulda MM, Kurachi Y. Essential role of nucleotide diphosphates in nicorandil-mediated activation of cardiac ATP-sensitive $\mathbf{K}^{+}$channels. Circ Res 1991; 69:1152-8

27. Jahangir A, Terzic A, Kurachi Y. Voltage-modulated action of aprikalim on cardiac ATP-sensitive $\mathrm{K}^{+}$channels. J Mol Cell Cardiol 1995;27:A25.

28. Hamada $E$, Takikawa $R$, Ito $H$, Iguchi $M$, Terano $A$, Sugimoto $\mathrm{T}$, et al. Glibenclamide specifically blocks ATPsensitive $\mathrm{K}^{+}$channels current in atrial myocytes of guinea pig heart. Jpn J Pharmacol 1990;54:473-7.

29. Findlay I. Inhibition of ATP-sensitive $\mathrm{K}^{+}$channels in cardiac muscle by the sulfonylurea drug glibenclamide. J Pharmacol Exp Ther 1992;261:540-5.

30. Lopez JR, Jovanovic A, Terzic A. Spontaneous calcium waves without contraction in cardiac myocytes. Biochem Biophys Res Commun 1995;214:781-7.

31. Vogel SM, Terzic A. $\alpha$-Adrenergic regulation of action potentials in isolated rat ventricular myocytes. Eur $\mathfrak{J}$ Pharmacol 1989;164:231-9.

32. Fabiato A. Simulated calcium current can both cause calcium loading in and trigger the calcium release from the sarcoplasmic reticulum of a skinned cardiac cell. J Gen Physiol 1985;85:291-320. 
33. Barry WH, Bridge JHB. Intracellular calcium homeostasis in cardiac myocytes. Circulation 1993;87:1806-15.

34. Diaco M, DiSesa VJ, Sun SC, Laurence R, Cohn LH. Cardioplegia for the immature myocardium: a comparative study in the neonatal rabbit. J Thorac Cardiovasc Surg 1990;100:910-3.

35. Piper HM, Siegmund B, Ladilov YuV, Schluter KD. Calcium and sodium control in hypoxic-reoxygenated cardiomyocytes. Basic Res Cardiol 1993;88:471-82.

36. Jynge $P$, Hearse DJ, Braimbridge MV. Myocardial protection during ischemic cardiac arrest: a possible hazard with calcium-free cardioplegic infusates. J Thorac Cardiovasc Surg 1977;73:848-55.

37. Steenbergen C, Murphy E, Watts J, London RE. Correlation between cytosolic free calcium, contracture, ATP, and irreversible ischemic injury in perfused rat heart. Circ Res 1990;66:135-46.

38. Tsukube T, McCulley JD, Faulk EA, Federman M, LoCicero J III, Krukenkamp IB, et al. Magnesium cardioplegia reduces cytosolic and nuclear calcium and DNA fragmentation in the senescent myocardium. Ann Thorac Surg 1994;58:1005-11.

39. Jahangir A, Terzic A, Kurachi Y. Intracellular acidification and ADP enhance nicorandil induction of ATP-sensitive potassium channel current in ventricular myocytes. Cardiovasc Res 1994:28:831-5.

40. Lopez JR, Ghanbari R, Terzic A. An opener of ATPsensitive $\mathrm{K}^{+}$channels protects cardiomyocytes from moder- ate hyperkalemia-induced $\mathrm{Ca}^{2+}$ waves: a laser confocal microscopy study. Am J Physiol 1996;39:H1384-9.

41. Escande D, Cavero I. $\mathrm{K}^{+}$channel openers and "natural" cardioprotection. Trends Pharmacol Sci 1992;13:269-72.

42. Auchampach JA, Maruyama M, Cavero I, Gross GJ. The new $\mathrm{K}^{+}$channel opener aprikalim (RP 52891) reduces experimental infarct size in dogs in the absence of hemodynamic changes. J Pharmacol Exp Ther 1991;259:961-7.

43. Pignac J, Bourgouin J, Dumont L. Cold cardioplegia and the $\mathrm{K}^{+}$channel modulator aprikalim (RP 52891): improved cardioprotection in isolated ischemic rabbit hearts. Can J Physiol Pharmacol 1994;72:126-32.

44. Damiano RJ, Cohen NM. Hyperpolarized arrest attenuates myocardial stunning following global surgical ischemia: an alternative to traditional hyperkalemic cardioplegia? J Card Surg 1994;9:517-25.

45. Sugimoto S, Iwashiro K, Monti F, Dawodu AA, Schiariti M, Puddu PE. The risk of myocardial stunning is decreased concentration-dependently by $\mathrm{K}_{\mathrm{ATP}}$ channel activation with nicorandil before high $\mathbf{K}^{+}$cardioplegia. Int J Cardiol 1995; 48:11-25.

46. Soncul H, Gökgöz L, Karasu C, Ayrancioğlu K, Ersöz A, et al. Comparison of potassium and adenosine cardioplegia with or without verapamil in the isolated guinea pig heart. Gen Pharmacol 1992;23:89-93.

47. Quast U. Potassium channel openers: pharmacological and clinical aspects. Fundam Clin Pharmacol 1992;6:279-93. 